Cite this: New J. Chem., 2014, 38,4083

Received (in Montpellier, France) 12th April 2014,

Accepted 27th May 2014

DOI: $10.1039 / c 4 n j 00564 c$

www.rsc.org/njc

\section{Vysotskite structured photoactive palladium sulphide thin films from dithiocarbamate derivatives $\uparrow$}

\author{
Muhammad Ali Ehsan, ${ }^{a}$ Huang Nay Ming, ${ }^{\mathrm{b}}$ Vickie McKee, ${ }^{\mathrm{c}}$ \\ Thalge Anton Nirmal Peiris, ${ }^{c}$ Upul Wijayantha-Kahagala-Gamage, ${ }^{c} Z_{\text {Zainudin }}$ Arifin $^{a}$ \\ and Muhammad Mazhar*a
}

\begin{abstract}
A series of palladium(॥) dithiocarbamate complexes $\left[\mathrm{Pd}\left(\mathrm{S}_{2} \mathrm{CNRR}\right)_{2}\right] \cdot n(\mathrm{py})$ [where py $=$ pyridine; $\mathrm{RR}^{\prime}=\mathrm{Bz}$, $n=1$ (1); Cy, $n=1$ (2); ${ }^{n} \mathrm{Hex}, n=0$ (3) and MeCy, $n=0$ (4)] have been synthesized and characterized using various physicochemical techniques and their single crystal structures have been established. The decomposition modes and potential of the complexes as single source precursors (SSPs) for the development of palladium sulphide (PdS) thin films were investigated by thermogravimetric and derivative thermogravimetric (TGA/DTG) analyses. The PdS thin films were deposited on FTO conducting glass substrates at 400,450 and $500{ }^{\circ} \mathrm{C}$ by the aerosol-assisted chemical vapour deposition (AACVD) technique and characterized by $\mathrm{X}$-ray diffraction (XRD), scanning electron microscopy (SEM), energy dispersive $\mathrm{X}$-ray analysis (EDX) reveal that the deposit has a tetragonal structure with a 1:1 ratio of $\mathrm{Pd}: \mathrm{S}$. The shape and size of PdS crystallites and the texture of films depend on the deposition temperatures and the precursor type used. The direct band gap energy of $1.56 \mathrm{eV}$ was estimated from UV-Vis spectroscopy of the PdS films fabricated from precursor (2) at $450{ }^{\circ} \mathrm{C}$. The photoelectrochemical (PEC) properties of PdS films were studied by recording the current-voltage plots under alternating dark and illumination conditions. To the best of our knowledge, this is the first demonstration of PEC studies of photoactive PdS thin films fabricated using the AACVD technique using palladium(॥) dithiocarbamate complexes as precursors.
\end{abstract}

\section{Introduction}

Transition metal sulphides exhibit diverse electrical, magnetic and optical properties ${ }^{1}$ which are fundamental to a range of technological applications such as solar cells, ${ }^{2}$ fuel cells, ${ }^{3}$ gas sensors, ${ }^{4}$ lithium ion batteries, ${ }^{5}$ spintronics light-emitting diodes, ${ }^{6}$ non-volatile memory, ${ }^{6}$ spin valve transistors light emitting diodes, ${ }^{6}$ laser devices, photoconductors ${ }^{7}$ and infrared detectors. ${ }^{7}$ Palladium sulphides exist in a variety of phases

\footnotetext{
${ }^{a}$ Department of Chemistry, Faculty of Science, University of Malaya, Lembah Pantai, 50603 Kuala Lumpur, Malaysia.E-mail: maliqau@ymail.com, zainudin@um.edu.my, mazhar42pk@yahoo.com; Tel: +60 (03)79674269

${ }^{b}$ Department of Physics, Faculty of Science, University of Malaya, Lembah Pantai, 50603 Kuala Lumpur, Malaysia.E-mail: huangnayming@gmail.com

${ }^{c}$ Department of Chemistry, Loughborough University, Loughborough, LE11 3TU, UK. E-mail: T.A.N.Peiris@lboro.ac.uk,u.wijayantha@lboro.ac.uk,

V.McKee@lboro.ac.uk; Tel: +44(0)1509222574

$\dagger$ Electronic supplementary information (ESI) available: Microanalysis results, H-NMR spectra, TGA plots, EDX spectra and single crystal X-ray crystallographic information. CCDC 995675-995678. For ESI and crystallographic data in CIF or other electronic format see DOI: 10.1039/c4nj00564c
}

including PdS, $\mathrm{PdS}_{2}, \mathrm{Pd}_{2.8} \mathrm{~S}, \mathrm{Pd}_{3} \mathrm{~S}, \mathrm{Pd}_{4} \mathrm{~S}, \mathrm{Pd}_{2.2} \mathrm{~S}$ and $\mathrm{Pd}_{2.5} \mathrm{~S}$. Of all these phases, only vystotskite $\mathrm{PdS}$ possesses a band gap energy $\left(E_{\mathrm{g}}\right)<2 \mathrm{eV}^{8}$ to exhibit semiconducting properties, which find potential applications in catalysis, ${ }^{9,10}$ ohmic contacts in semiconducting electronic devices, acid resistant high temperature electrodes, ${ }^{11}$ recording films in optical discs and lithographic films, ${ }^{12}$ and light image receiving materials with silver halides. ${ }^{13}$ PdS is a widely explored material and has been largely synthesized in powder forms as well as nano-crystals using a variety of methods. Nano-crystals have been synthesized by solvothermal or thermal decomposition of palladium(II) xanthate and allyl palladium(II) xanthate complexes. ${ }^{14}$ The aqueous dispersions of PdS particles have been prepared by the addition of $\mathrm{Na}_{2} \mathrm{~S}$ solution to $\mathrm{PdCl}_{2}$ or $\mathrm{Na}_{2} \mathrm{PdCl}_{4}$ solutions. ${ }^{15}$ Organosols of PdS have been synthesized by the reaction of metal acetate with hydrogen sulphide. ${ }^{16}$ However, relatively few reports have been published on the deposition of PdS thin films using either a chemical vapour deposition (CVD) or a non-CVD technique. The single source precursor (SSP) based CVD synthetic approach has been identified as a potential route for the fabrication of tailormade thin films that can meet the technology demand in 
industry today. In recent years, the classes of compounds investigated for the deposition of PdS thin films were xanthate $\left[\mathrm{Pd}\left(\mathrm{S}_{2} \mathrm{CO}^{\mathrm{i}} \mathrm{Pr}\right)_{2}\right],\left[\mathrm{Pd}\left(\mathrm{S}_{2} \mathrm{COCHMe}\right)_{2}\right],{ }^{17}$ dithiocarbamate $\mathrm{Pd}\left(\mathrm{S}_{2} \mathrm{CNRR}^{\prime}\right)_{2}$ $\left(\mathrm{RR}^{\prime}=\mathrm{Et}_{2}, \mathrm{MeEt}, \mathrm{Me}^{n} \mathrm{Bu} \text {, or } \mathrm{Me}^{n} \mathrm{Hex}\right)^{18,19}$ and allylpalladium dithiocarbamate $\left[\left(\eta^{3}-\mathrm{C}_{3} \mathrm{H}_{5}\right) \operatorname{Pd}\left(\mathrm{S}_{2} \mathrm{CNMe}{ }^{n} \mathrm{Hex}\right)\right] \cdot{ }^{20}$ However PdS thin films deposited from these SSPs have not been investigated thoroughly for technological applications.

Recently we have developed a number of semiconducting metal sulphides that harvest the entire solar spectrum for PEC and photovoltaic (PV) applications; $;^{21-25}$ therefore, the aim of the current research is to investigate the suitability of the AACVD-deposited PdS thin films by using palladium(II) dithiocarbamate precursors for such applications. Our research features the design and synthesis of SSPs for the development of thin film electrodes through the low-cost AACVD ${ }^{26,27}$ technique that is particularly valuable to assemble high quality semiconducting thin films in a single step with controlled surface morphologies. For the preparation of metal sulphide thin films, we have targeted dithiocarbamate complexes as precursors since we have previously found that such compounds are simple to synthesize, easy to handle, stable in air and moisture, exhibit high volatility and are expected to undergo simple and clean decomposition, making them ideal for use in the AACVD technique. ${ }^{21-25}$

The work reported here describes the synthesis of four palladium(II) dithiocarbamate complexes $\left[\mathrm{Pd}\left(\mathrm{S}_{2} \mathrm{CNRR}^{\prime}\right)_{2}\right] \cdot n(\mathrm{py})$ [where py = pyridine; $\mathrm{RR}^{\prime}=\mathrm{Bz}, n=1$ (1); Cy, $n=1$ (2); ${ }^{n} \mathrm{Hex}, n=0$ (3) and MeCy $n=0$ (4)], their complete characterization and use as precursors for the deposition of PdS thin films by AACVD method. PdS thin film characterizations such as a crystalline phase, degree of crystallinity, surface morphology, composition and optical band gap have been obtained by XRD, SEM, EDX and UV-Vis spectrophotometry. Furthermore, the photoelectrochemical (PEC) responses of PdS films were also investigated in order to evaluate their photoactivity.

\section{Experimental}

\subsection{Materials and methods}

All preparations were performed at room temperature. All reagents were purchased from Sigma Aldrich and used as received. The dithiocarbamate ligands were prepared according to published procedures. ${ }^{28}$ The elemental analyses were carried out using a Perkin Elmer CHNS/O Analyzer series II 2400. The infrared spectra were recorded in the range $4000-400 \mathrm{~cm}^{-1}$ on a Perkin Elmer Spectrum 400 FT-IR/FT-FIR spectrophotometer. Thermogravimetric studies were performed on a METTLER TOLEDO TGA/SDTA 851e TGA analyzer under a heating rate of $10{ }^{\circ} \mathrm{C} \min ^{-1}$ under flowing dry nitrogen gas.

\subsection{General procedure for the synthesis of $\left[\operatorname{Pd}\left(\mathrm{S}_{2} \mathrm{CNRR}^{\prime}\right)_{2}\right]$. $n$ (py) complexes, (1)-(4)}

Two equivalents of sodium dibenzyldithiocarbamate $(0.50 \mathrm{~g}$, $1.70 \mathrm{mmol})$ and palladium nitrate dihydrate $(0.23 \mathrm{~g}, 0.86 \mathrm{mmol})$ were dissolved in acetone $(50 \mathrm{~mL})$ and the resultant dark yellow solution was stirred for $30 \mathrm{~min}$, whereupon pyridine $(30 \mathrm{~mL})$ was added to give a clear yellow solution and stirring was continued for another hour. Filtration and slow evaporation of the reaction mixture afforded $\left[\mathrm{Pd}\left(\mathrm{S}_{2} \mathrm{CNBz}_{2}\right)_{2}\right]$.py $(\mathbf{1})$ as yellow crystals, yield $(0.48 \mathrm{~g}, 77 \%) \mathrm{mp} .225-228{ }^{\circ} \mathrm{C}$. Elemental analysis (found: $\mathrm{C}, 57.91 ; \mathrm{H}, 4.33 ; \mathrm{N}, 5.52 \% ; \mathrm{C}_{35} \mathrm{H}_{33} \mathrm{PdN}_{3} \mathrm{~S}_{4}$ requires $\mathrm{C}$, 57.51; H, 4.51; N 5.75\%); IR ( $\left.\nu_{\max } / \mathrm{cm}^{-1}\right)$ : 3062w, 3026m, 2922w, $2322 \mathrm{w}, 2067 \mathrm{brw}, 1884 \mathrm{brw}, 1804 \mathrm{w}, 1604 \mathrm{w}, 1585 \mathrm{w}, 1491 \mathrm{~s}, 1452 \mathrm{~s}$, $1427 \mathrm{~m}, 1357 \mathrm{~s}, 1312 \mathrm{w}, 1253 \mathrm{~s}, 1221 \mathrm{~s}, 1145 \mathrm{~s}, 1076 \mathrm{~s}, 1030 \mathrm{~s}, 989 \mathrm{~s}$, 929s, 901w, 882s, 822m, 744s, 736s, 691s, 639w, 626m, 585s, 557s, 538s, 516s; ${ }^{1} \mathrm{H}-\mathrm{NMR} \delta_{\mathrm{H}}\left(400 \mathrm{MHz}, \mathrm{CDCl}_{3}\right) 4.81(8 \mathrm{H}, \mathrm{s}$, $\left.4\left(\mathrm{CH}_{2}\right)\right)$ and $7.26-7.42\left(20 \mathrm{H}, \mathrm{m}\right.$, aromatic $\left.4\left(\mathrm{C}_{6} \mathrm{H}_{5}\right)\right) \mathrm{ppm}$ and 7.66-8.62 ppm (5H, m, $\left.\left(\mathrm{NC}_{5} H_{5}\right)\right)$; TGA: $66-139{ }^{\circ} \mathrm{C}(6.02 \% \mathrm{wt}$ loss); $238-500{ }^{\circ} \mathrm{C}$ (76.28\% wt loss); (residual mass of $\left.17.70 \%\right)$; (cal. for PdS $18.90 \%$ ).

Similarly, complexes $\left[\mathrm{Pd}\left(\mathrm{S}_{2} \mathrm{CNCy}_{2}\right)_{2}\right] \cdot \operatorname{py}(2),\left[\mathrm{Pd}\left(\mathrm{S}_{2} \mathrm{CN}^{n} \mathrm{Hex}_{2}\right)_{2}\right]$ (3) and $\left[\mathrm{Pd}\left(\mathrm{S}_{2} \mathrm{CNCyMe}\right)_{2}\right]$ (4) were prepared as yellow and dark brown crystals. The quantities of the reactants used and the analytical data are as follows:

(2). Sodium dicyclohexyldithiocarbamate $(0.50 \mathrm{~g}, 1.80 \mathrm{mmol})$ and palladium nitrate dihydrate $(0.24 \mathrm{~g}, 0.90 \mathrm{mmol})$; yield (0.49 g, 78\%), mp. 265-270 ${ }^{\circ} \mathrm{C}$ (decomposition). Elemental analysis (found: C, 52.86; $\mathrm{H}, 7.31 ; \mathrm{N}, 5.84 \% ; \mathrm{C}_{31} \mathrm{H}_{49} \mathrm{PdN}_{3} \mathrm{~S}_{4}$ requires $\mathrm{C}, 53.26 ; \mathrm{H}, 7.01 ; \mathrm{N}, 6.01 \%) ; \mathrm{IR}\left(\nu_{\max } / \mathrm{cm}^{-1}\right): 2927 \mathrm{~s}$, 2854 s, 2657w, 2091brw, 1596w, 1579m, 1475s, 1460w, 1447w, $1435 \mathrm{w}, 1366 \mathrm{~s}, 1348 \mathrm{~s}, 1302 \mathrm{~s}, 1270 \mathrm{~s}, 1164 \mathrm{~s}, 1152 \mathrm{w}, 1108 \mathrm{~s}, 1065 \mathrm{w}$, $1028 \mathrm{~m}, 998 \mathrm{~s}, 949 \mathrm{~m}, 924 \mathrm{~s}, 895 \mathrm{~s}, 883 \mathrm{w}, 844 \mathrm{w}, 800 \mathrm{w}, 747 \mathrm{~s}, 708 \mathrm{~s}$, 663s, 613s, 596w, 504w, 489m, 470m; ${ }^{1} \mathrm{H}-\mathrm{NMR} \delta_{\mathrm{H}}(400 \mathrm{MHz}$, $\left.\mathrm{CDCl}_{3}\right) 4.74(2 \mathrm{H}, \mathrm{s},(\mathrm{NCH})), 2.87(2 \mathrm{H}, \mathrm{s},(\mathrm{NCH})), 1.10-1.78$ $\left(40 \mathrm{H}, \mathrm{m}, 2\left(\mathrm{C}_{10} H_{20}\right)\right)$ and $7.42-8.71 \mathrm{ppm}\left(5 \mathrm{H}, \mathrm{m},\left(\mathrm{NC}_{5} H_{5}\right)\right)$; TGA: $75-163{ }^{\circ} \mathrm{C}(8.38 \%$ wt loss $) ; 252-500{ }^{\circ} \mathrm{C}$ (72.42\% wt loss); (residual mass of $19.20 \%$ ); (cal. for PdS $19.77 \%$ ).

(3). Sodium di- $n$-hexyldithiocarbamate $(0.50 \mathrm{~g}, 1.76 \mathrm{mmol})$ and palladium nitrate dihydrate $(0.23 \mathrm{~g}, 0.88 \mathrm{mmol})$; yield (0.46 g, 81\%), mp. 61-64 ${ }^{\circ} \mathrm{C}$. Elemental analysis (found: C, 49.79; H, 8.10; N, 4.51\%; $\mathrm{C}_{26} \mathrm{H}_{52} \mathrm{PdN}_{2} \mathrm{~S}_{4}$ requires $\mathrm{C}, 49.73 ; \mathrm{H}$, $8.28 ; \mathrm{N}, 4.46 \%)$; IR $\left(\nu_{\max } / \mathrm{cm}^{-1}\right): 2954 \mathrm{~m}, 2923 \mathrm{~s}, 2854 \mathrm{~s}, 1510 \mathrm{~s}$, $1459 \mathrm{w}, 1430 \mathrm{~s}, 1371 \mathrm{~s}, 1300 \mathrm{~s}, 1278 \mathrm{w}, 1258 \mathrm{~s}, 1234 \mathrm{~m}, 1219 \mathrm{w}$, $1199 \mathrm{~m}, 1151 \mathrm{~s}, 1119 \mathrm{w}, 1100 \mathrm{~s}, 1054 \mathrm{w}, 1029 \mathrm{~m}, 972 \mathrm{brs}, 793 \mathrm{w}$, 724s, 626w, 606m, 575w, 534w, 518w; ${ }^{1} \mathrm{H}-\mathrm{NMR} \delta_{\mathrm{H}}(400 \mathrm{MHz}$, $\left.\mathrm{CDCl}_{3}\right)$ 3.83-3.57 (8H, m, 4( $\left.\left.\mathrm{CH}_{2}\left(\mathrm{CH}_{2}\right)_{4} \mathrm{CH}_{3}\right)\right), 1.64(8 \mathrm{H}, \mathrm{s}$, $\left.4\left(\mathrm{CH}_{2} \mathrm{CH}_{2}\left(\mathrm{CH}_{2}\right)_{3} \mathrm{CH}_{3}\right)\right) ; 1.27\left(24 \mathrm{H}, \quad \mathrm{s}, 4\left(\mathrm{CH}_{2} \mathrm{CH}_{2}\left(\mathrm{CH}_{2}\right)_{3} \mathrm{CH}_{3}\right)\right)$ and $0.87\left(12 \mathrm{H}, \mathrm{s}, 4\left(\left(\mathrm{CH}_{2}\right)_{5} \mathrm{CH}_{3}\right)\right)$ ppm; TGA: 200-515 ${ }^{\circ} \mathrm{C}$ (78.22\% wt loss); (residual mass of 21.78\%); (cal. for PdS $22.00 \%)$.

(4). Sodium methyl cyclohexyl dithiocarbamate $(0.5 \mathrm{~g}$, $2.36 \mathrm{mmol})$ and palladium nitrate dihydrate $(0.31 \mathrm{~g}, 1.18 \mathrm{mmol})$; yield (0.46 g, 81\%), mp. $185{ }^{\circ} \mathrm{C}$. Elemental analysis (found: $\mathrm{C}$, 40.17; H, 5.89; N, 5.93\% $\mathrm{C}_{16} \mathrm{H}_{28} \mathrm{PdN}_{2} \mathrm{~S}_{4}$ requires C, 39.75; $\mathrm{H}, 5.79$; $\mathrm{N}, 5.79 \%)$; IR $\left(\nu_{\max } / \mathrm{cm}^{-1}\right): 2933 \mathrm{~s}, 2855 \mathrm{~s}, 1490 \mathrm{~s}, 1447 \mathrm{~m}, 1397 \mathrm{~s}$, $1373 \mathrm{~m}, 1345 \mathrm{w}, 1322 \mathrm{~s}, 1251 \mathrm{~s}, 1213 \mathrm{~s}, 1188 \mathrm{~m}, 1147 \mathrm{~s}, 1112 \mathrm{w}, 1078 \mathrm{~s}$, $1058 \mathrm{w}, 1031 \mathrm{~m}, 1005 \mathrm{~s}, 966 \mathrm{~s}, 913 \mathrm{~s}, 892 \mathrm{~s}, 874 \mathrm{w}, 786 \mathrm{w}, 746 \mathrm{w}, 703 \mathrm{w}$, 669s, 570s, 516s, 461s; ${ }^{1} \mathrm{H}-\mathrm{NMR} \delta_{\mathrm{H}}\left(400 \mathrm{MHz}, \mathrm{CDCl}_{3}\right) 4.48$ $(2 \mathrm{H}, \mathrm{m}, 2(\mathrm{NCH})), 3.07\left(6 \mathrm{H}, \mathrm{s}, 2\left(\mathrm{CH}_{3}\right)\right), 1.08-1.03(20 \mathrm{H}, \mathrm{m}$, 2( $\left.\left.\mathrm{C}_{5} H_{10}\right)\right)$ ppm; TGA: $210-500{ }^{\circ} \mathrm{C}$ (wt loss $72.60 \%$ ); (residual mass of $27.40 \%$ ); (cal. for PdS $28.57 \%$ ). 


\subsection{Deposition of thin films by AACVD}

The details of $\mathrm{PdS}$ thin films grown from precursors $\left[\mathrm{Pd}\left(\mathrm{S}_{2} \mathrm{CNBz}_{2}\right)_{2}\right] \cdot$ py (1) $\left[\mathrm{Pd}\left(\mathrm{S}_{2} \mathrm{CNCy}_{2}\right)_{2}\right] \cdot$ py (2), $\left[\mathrm{Pd}\left(\mathrm{S}_{2} \mathrm{CN}^{n} \mathrm{Hex}_{2}\right)_{2}\right]$ (3) and $\left[\mathrm{Pd}\left(\mathrm{S}_{2} \mathrm{CNCyMe}\right)_{2}\right](4)$ on FTO $\left(1 \times 2 \mathrm{~cm}^{2}\right)$ glass substrates (TEC $15,15 \Omega$ per square) by using the AACVD technique, are given elsewhere. ${ }^{29}$ The glass substrate was cleaned prior to use by washing successively with distilled water, acetone and ethyl alcohol. For each PdS film deposition, 0.05 M pyridine solution of each precursor was taken into a $50 \mathrm{~mL}$ round-bottom flask with a gas inlet that allowed the carrier gas (Ar) to pass into the solution to aid the transport of the aerosol. Ar at a flow rate of

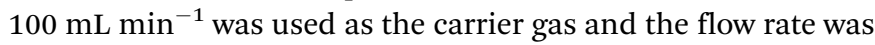
controlled by an L1X linear flowmeter. Substrate slides were placed inside the reactor tube which was placed in a furnace (CARBOLITE, Model No. 10/25/130) $\left(6^{\prime \prime} \mathrm{L} \times 1^{\prime \prime} \mathrm{D}\right)$ and heated up to the desired temperature before deposition from (1) to (4). The aerosols of the precursor solution were formed in a roundbottom flask in a water bath above the piezoelectric modulator of an ultrasonic humidifier (Model No. Cool Mist-plus serial No. ADV-CMP-85956). The aerosol droplets of the precursor were then transferred into the hot wall zone of the reactor by the carrier gas. Both the solvent and the precursor were evaporated and the precursor vapour reached the heated substrate surface where thermally induced reactions and subsequent film deposition took place.

\subsection{X-ray crystallography}

The XRD analysis of complexes (1)-(4) was done at 150(2) K on a Bruker Apex II CCD diffractometer using $\mathrm{MoK}_{\alpha}$ radiation $(\alpha=0.71073 \AA)$. The structure was solved by direct methods and refined on $F^{2}$ using all the reflections. ${ }^{30}$ Except where described below, all the non-hydrogen atoms were refined using anisotropic atomic displacement parameters and hydrogen atoms were inserted at calculated positions using a riding model. The crystal data, data collection and structure refinement details are summarized in Table 1.

The pyridine solvated molecule in the complex $\left[\mathrm{Pd}\left(\mathrm{S}_{2} \mathrm{CNCy}_{2}\right)_{2}\right] \cdot$ py (2) is disordered over a centre of symmetry; the nitrogen atom is therefore necessarily disordered and was modelled with 50\% occupancy of two positions. There is some disorder in one of the four independent alkyl chains of $\left[\mathrm{Pd}\left(\mathrm{S}_{2} \mathrm{CN}^{n} \mathrm{Hex}_{2}\right)_{2}\right](4)$. The four terminal carbon atoms of this chain were modelled with a $74: 26 \%$ occupancy of two orientations and the minor component was refined isotropically.

\subsection{Thin film characterization}

The X-ray diffraction data of the films were collected on a PANalytical, X'Pert HighScore diffractometer with primary monochromatic high intensity $\mathrm{Cu}-\mathrm{K}_{\alpha}(\lambda=1.54184 \AA)$ radiation. The data were collected by scanning from $15^{\circ}$ to $90^{\circ}$ in a step size of $0.026^{\circ}$ operated at $40 \mathrm{kV}$ and $40 \mathrm{~mA}$ to cover all possible diffraction peaks of the deposited material.

Film morphology and composition were determined using a field-emission gun scanning electron microscope (FE-SEM, FEI Quanta 400) equipped with an energy dispersive X-ray spectrometer EDX (INCA Energy 200, Oxford Inst.) operated at an accelerating voltage of $20 \mathrm{kV}$ and a working distance of $9.2 \mathrm{~mm}$.

\subsection{Optical and photoelectrochemical characterization}

The optical absorbance of thin films was recorded on a Lambda 35 Perkin-Elmer UV-Vis spectrophotometer. The data were registered from 400 to $900 \mathrm{~nm}$ using an FTO glass substrate as a reference. The PEC properties of PdS electrodes were measured using a standard three electrode electrochemical cell fitted with a quartz window. $\mathrm{An} \mathrm{Ag} / \mathrm{AgCl}$ electrode and Pt were employed as the reference and counter electrodes respectively,

Table 1 Crystal data and refinement parameters for the complexes $\left[\mathrm{Pd}\left(\mathrm{S}_{2} \mathrm{CNBz}_{2}\right)_{2}\right] \cdot \mathrm{py}(\mathbf{1})\left[\operatorname{Pd}\left(\mathrm{S}_{2} \mathrm{CNCy}_{2}\right)_{2}\right] \cdot \mathrm{py}(\mathbf{2})$, $\left[\mathrm{Pd}\left(\mathrm{S}_{2} \mathrm{CN}^{n} \mathrm{Hex}_{2}\right)_{2}\right] \quad(\mathbf{3})$ and $\left[\mathrm{Pd}\left(\mathrm{S}_{2} \mathrm{CNCyMe}\right)_{2}\right](4)$

\begin{tabular}{|c|c|c|c|c|}
\hline & (1) & (2) & (3) & (4) \\
\hline Empirical formula & $\mathrm{C}_{35} \mathrm{H}_{33} \mathrm{~N}_{3} \mathrm{PdS}_{4}$ & $\mathrm{C}_{31} \mathrm{H}_{49} \mathrm{~N}_{3} \mathrm{PdS}_{4}$ & $\mathrm{C}_{26} \mathrm{H}_{52} \mathrm{~N}_{2} \mathrm{PdS}_{4}$ & $\mathrm{C}_{16} \mathrm{H}_{28} \mathrm{~N}_{2} \mathrm{PdS}_{4}$ \\
\hline Formula weight & 730.28 & 698.37 & 627.33 & 483.04 \\
\hline Crystal system & Monoclinic & Monoclinic & Orthorhombic & Monoclinic \\
\hline Space group & $C 2 / c$ & $P 2_{1} / n$ & Pbca & $\mathrm{P} 22_{1} / n$ \\
\hline Unit cell $a(\AA)$ & $20.803(3)$ & $9.9610(13)$ & $12.3351(11)$ & $9.9199(7)$ \\
\hline$b(\AA)$ & $6.3637(8)$ & $14.0277(19)$ & $20.5728(19)$ & $11.0292(7)$ \\
\hline$c(\AA)$ & $25.240(3)$ & $12.1552(16)$ & $25.918(2)$ & $10.1444(7)$ \\
\hline$\beta\left(^{\circ}\right)$ & $99.136(2)$ & $104.023(2)$ & 90 & $114.6960(10)$ \\
\hline Volume $\left(\AA^{3}\right)$ & $3299.0(7)$ & $1647.8(4)$ & $6577.2(10)$ & $1008.37(12)$ \\
\hline$Z$ & 4 & 2 & 8 & 2 \\
\hline$D$ (calc) $\left(\mathrm{Mg} \mathrm{m}^{-3}\right)$ & 1.470 & 1.408 & 1.267 & 1.591 \\
\hline Abs coeff. $\left(\mathrm{mm}^{-1}\right)$ & 0.845 & 0.842 & 0.834 & 1.335 \\
\hline$F(000)$ & 1496 & 732 & 2656 & 496 \\
\hline Crystal size $\left(\mathrm{mm}^{3}\right)$ & $0.40 \times 0.24 \times 0.07$ & $0.20 \times 0.16 \times 0.16$ & $0.34 \times 0.24 \times 0.15$ & $0.28 \times 0.22 \times 0.20$ \\
\hline Crystal description & Yellow lath & Yellow block & Yellow block & Yellow block \\
\hline$\theta$ range $\left(^{\circ}\right)$ & $1.634-28.325$ & $2.256-28.347$ & $1.571-28.315$ & $2.412-31.804$ \\
\hline Reflections collected & 16346 & 16333 & 64543 & 11825 \\
\hline Ind. refl $\left[R_{\mathrm{int}}\right]$ & $4121[0.0385]$ & $4109[0.0478]$ & $8186[0.0704]$ & $3217[0.0298]$ \\
\hline Data/restraints/param & $4121 / 0 / 197$ & $4109 / 0 / 178$ & $8186 / 20 / 311$ & $3217 / 0 / 107$ \\
\hline Goof on $F^{2}$ & 1.049 & 0.999 & 1.010 & 1.063 \\
\hline$R_{1}, \mathrm{w} R_{2}[I>2 s(I)]$ & $0.0283,0.0606$ & $0.0348,0.0773$ & $0.0375,0.0817$ & $0.0262,0.0623$ \\
\hline$R_{1}, \mathrm{w} R_{2}$ [all data] & $0.0378,0.0640$ & $0.0519,0.0832$ & $0.0731,0.0955$ & $0.0327,0.0651$ \\
\hline \pm Residuals $\left({\left.\mathrm{e} \AA^{-3}\right)}^{-3}\right.$ & $0.406,-0.467$ & $0.479,-0.758$ & $0.375,-0.864$ & $0.651,-0.600$ \\
\hline
\end{tabular}


and all the measurements were carried out in a $1 \mathrm{M} \mathrm{Na}_{2} \mathrm{SO}_{3}$ aqueous electrolyte. ${ }^{31}$ Chopped current-voltage measurements of the cells were carried out using a potentiostat (Eco Chemie micro-Autolab type III), while the cells were illuminated using an AM 1.5 Class A solar simulator (Solar Light 16S-300 solar simulator), at $100 \mathrm{~mW} \mathrm{~cm}{ }^{-2}$ light intensity, calibrated by a silicon pyranometer (Solar Light Co., PMA2144 Class II). The effective area of the photoelectrode was maintained at $1 \mathrm{~cm}^{2}$.

\section{Results and discussion}

\subsection{Preparation and characterization of complexes}

The palladium(II) nitrate dihydrate reacts with sodium dithiocarbamate in a stoichiometric ratio of $1: 2$ in acetone pyridine solution to yield mononuclear complexes $\left[\mathrm{Pd}\left(\mathrm{S}_{2} \mathrm{CNRR}^{\prime}\right)_{2}\right] \cdot n(\mathrm{py})$ [where py = pyridine; $\mathrm{RR}^{\prime}=\mathrm{Bz}, n=1$ (1); Cy, $n=1(2) ;{ }^{n} \mathrm{Hex}, n=0$ (3) and MeCy $n=0$ (4)] as shown in reaction (1). The reaction proceeds through a metathetical reaction with the elimination of sodium nitrate and the complexes were isolated as dry crystalline solids, varying in appearance from yellow (1)-(3) to dark brown (4) and readily soluble in common organic solvents, THF, pyridine and chloroform. An earlier method reported ${ }^{18}$ for the preparation of such SSPs involves the in situ synthesis of dithiocarbamates followed by the reaction with $\mathrm{Na}_{2}\left[\mathrm{PdCl}_{4}\right]$ aqueous solutions. Thus the prepared complexes needed to be dried in a vacuum for several days and subsequently needed sublimation to obtain pure products. This synthetic strategy enabled us to obtain pure crystalline product from the acetonepyridine mixture.

$$
\begin{aligned}
& \mathrm{PdNO}_{3} \cdot 2 \mathrm{H}_{2} \mathrm{O}+2 \mathrm{Na}\left(\mathrm{S}_{2} \mathrm{CNRR}^{\prime}\right) \\
& \text { Acetone Pyridine } \\
& \left.\left[{\mathrm{Pd}\left(\mathrm{S}_{2} \mathrm{CNRR}\right.}^{\prime}\right)_{3}\right] \cdot \mathrm{n}(\mathrm{py})+2 \mathrm{NaNO}_{3} \\
& \mathrm{RR}^{\prime}=\mathrm{Bz}, \mathrm{n}=1(\mathbf{1}) ; \mathrm{Cy}, \mathrm{n}=1(\mathbf{2}) \\
& { }^{\mathrm{n}} \mathrm{Hex}, \mathrm{n}=0(\mathbf{3}) ; \mathrm{MeCy}, \mathrm{n}=0 \text { (4) }
\end{aligned}
$$

The stoichiometry of the complexes (1)-(4) has been formulated on the basis of elemental analysis, IR, ${ }^{1} \mathrm{H}-\mathrm{NMR}$, and single crystal X-ray analyses. The microanalysis (CHN) of all complexes match well with their compositions calculated from the crystal data. The IR spectrum of all complexes (1)-(4) shows typical absorptions between $1427-1510 \mathrm{~cm}^{-1}$ due to $\nu(\mathrm{C}=\mathrm{N})$ stretching vibrations. The absorption bands in the region of $966 \mathrm{~cm}^{-1}$ and $1030 \mathrm{~cm}^{-1}$ are characteristic of the stretching vibrations of the $\nu$ (CSS $)_{\text {sym }}$ and $\nu$ (CSS $)_{\text {asym }}$ respectively and support the bidentate coordination of the $\mathrm{S}$ atoms of dithiocarbamate moieties with a metal centre. ${ }^{32,33}$ The ${ }^{1} \mathrm{H}$-NMR spectra of complexes (1)-(4) reveal the usual splitting patterns for protons attached to the corresponding $\mathrm{R}$ groups. The ${ }^{1} \mathrm{H}$-NMR spectra of complexes (1)-(2) show multiple peaks centred between $\delta 7.31$ and $8.70 \mathrm{ppm}$ due to the protons of the pyridine ring.

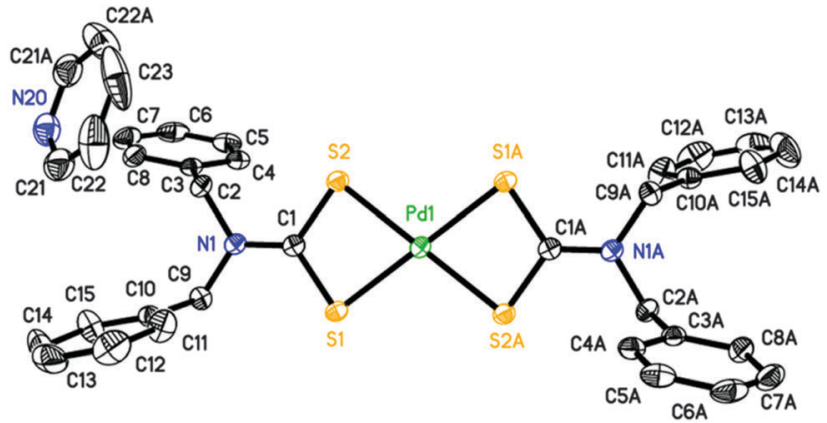

Fig. 1 Perspective view of $\left[\mathrm{Pd}\left(\mathrm{S}_{2} \mathrm{CNBz}_{2}\right)_{2}\right]$.py (1) showing $50 \%$ ellipsoids, hydrogen atoms have been omitted for clarity and the disorder of the pyridine solvate is not shown. Atoms with label suffix $A$ have been generated by inversion (symmetry operations $1-x, 1-y, 1-z$ for the complex and $1-x, 1-y,-z$ for the pyridine).

However such peaks are not observed in the spectra of complexes (3)-(4), which suggests the absence of pyridine in their molecular structures. Further evidence in this regard has been provided by thermogravimetric/derivative thermogravimetric and single crystal X-ray analyses of these complexes.

\subsection{Crystal structures of (1)-(4)}

Perspective views of the four $\left[\mathrm{Pd}\left(\mathrm{S}_{2} \mathrm{CNRR}^{\prime}\right)_{2}\right] \cdot n(\mathrm{py})[$ where py $=$ pyridine; $\mathrm{RR}^{\prime}=\mathrm{Bz}, n=1$ (1); Cy, $n=1$ (2); ${ }^{n} \mathrm{Hex}, n=0$ (3) and MeCy $n=0(4)]$ molecules are shown in Fig. 1-4. The coordination environment of the metal ion is very similar in each complex (Table 2). The palladium ion lies on a centre of symmetry in $\left[\operatorname{Pd}\left(\mathrm{S}_{2} \mathrm{CNBz}_{2}\right)_{2}\right] \cdot \operatorname{py}(\mathbf{1})\left[\operatorname{Pd}\left(\mathrm{S}_{2} \mathrm{CNCy}_{2}\right)_{2}\right] \cdot$ py (2) and $\left[\mathrm{Pd}\left(\mathrm{S}_{2} \mathrm{CNCyMe}\right)_{2}\right](4)$ but there is no crystallographically imposed symmetry in $\left[\mathrm{Pd}\left(\mathrm{S}_{2} \mathrm{CN}^{n} \mathrm{Hex}_{2}\right)_{3}\right]$ (3). In each complex the palladium is coordinated to two deprotonated dithiocarbamate groups and the $\mathrm{PdS}_{4}$ moiety is planar. The S-Pd-S bite angle for each ligand is approximately $75^{\circ}$ (Table 2), so preventing the adoption of a regular square planar coordination geometry.

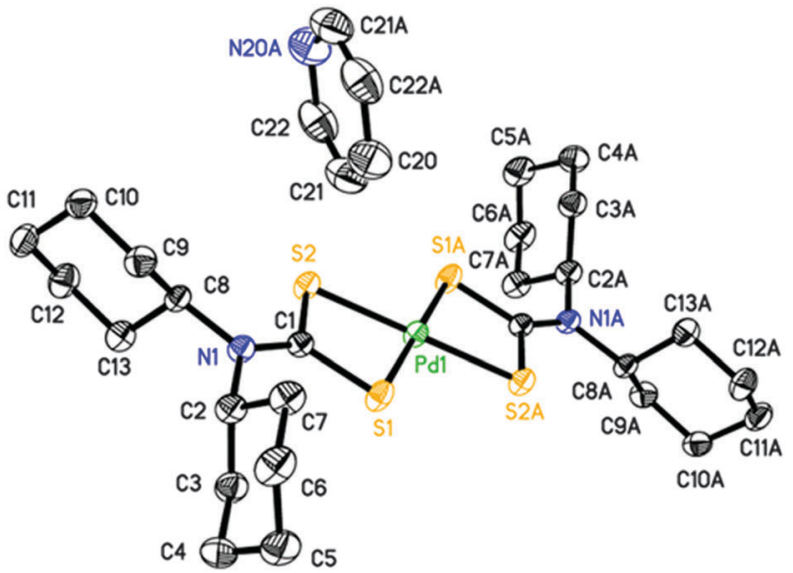

Fig. 2 Perspective view of $\left[\mathrm{Pd}\left(\mathrm{S}_{2} \mathrm{CNCy}_{2}\right)_{2}\right]$.py (2) showing $50 \%$ ellipsoids. Hydrogen atoms have been omitted for clarity and the disorder of the pyridine solvate is not shown. Atoms with label suffix $A$ have been generated by inversion (symmetry operations $1-x, 1-y, 1-z$ for the complex and $1-x, 1-y,-z$ for the pyridine). 


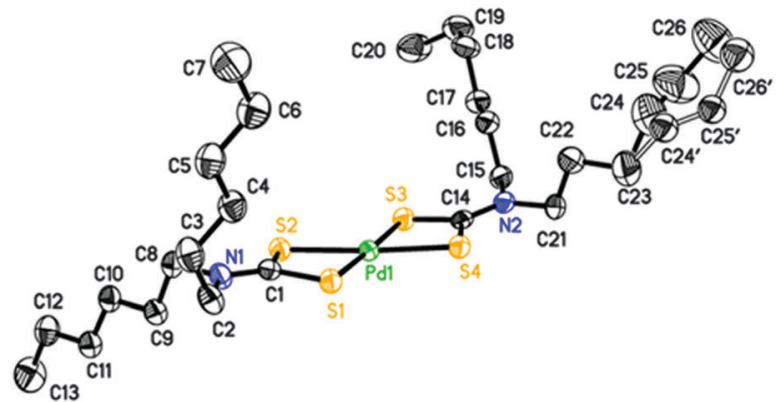

Fig. 3 Perspective view of $\left[\mathrm{Pd}\left(\mathrm{S}_{2} \mathrm{CN}^{n} \mathrm{Hex}_{2}\right)_{2}\right]$ (3) showing $50 \%$ ellipsoids. Hydrogen atoms have been omitted for clarity. Atoms with label suffix (') represent the minor component of a disorder modelled with $74: 26 \%$ occupancy of the two sites shown.

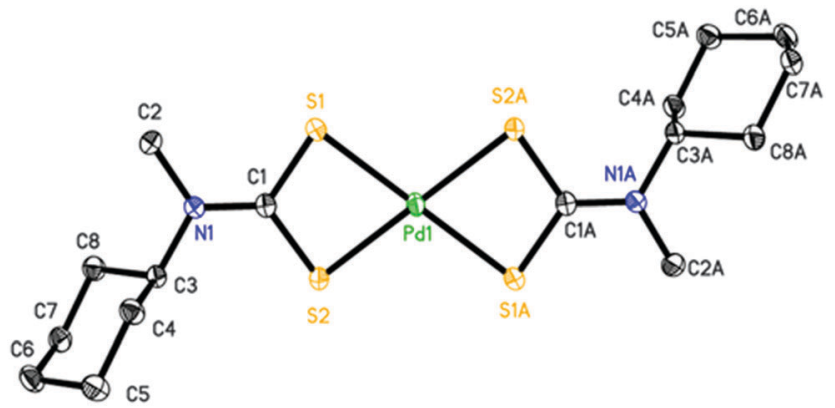

Fig. 4 Perspective view of $\left[\mathrm{Pd}\left(\mathrm{S}_{2} \mathrm{CNMeCy}\right)_{2}\right]$ (4) showing $50 \%$ ellipsoids. Hydrogen atoms have been omitted for clarity. Atoms with label suffix $A$ have been generated by inversion (symmetry operation $2-x,-y, 2-z$ )

The unit cell packing is different in each case, controlled by the substituents on the dithiocarbamate ligands (and incorporated solvate molecules).

\subsection{Thermogravimetric (TGA/DTG) analysis of precursors (1)-(4)}

The suitability of palladium dithiocarbamate complexes (1)-(4) for use as SSP for the deposition of PdS thin films was studied by TGA/DTG (Fig. S5a-d, ESI $\dagger$ ). It was revealed that the pyridine solvated complexes (1) and (2) display four-steps while the nonsolvated (3) and (4) show a three-step decomposition to leave a residue of PdS. The initial mass losses from (1) and (2) occur in the temperature ranges of $66-139$ and $75-163{ }^{\circ} \mathrm{C}$ with maximum heat intake steps at 97 and $124{ }^{\circ} \mathrm{C}$ respectively and are associated

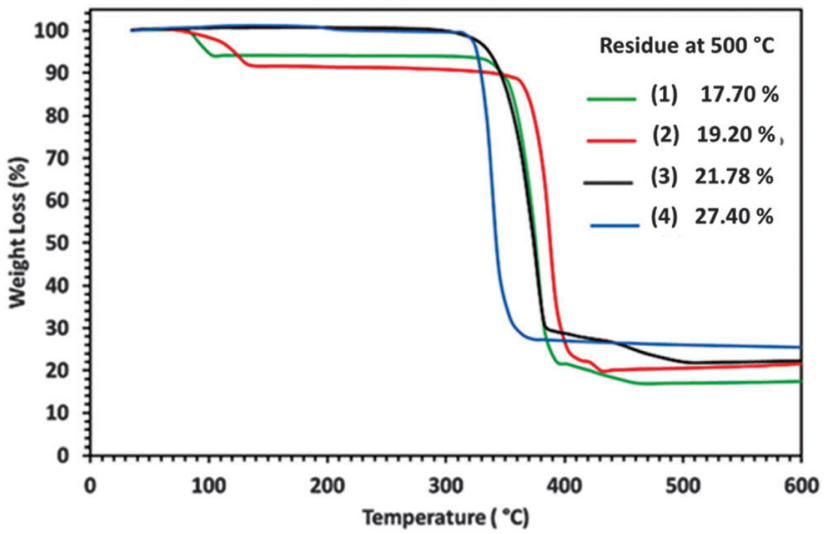

Fig. 5 Thermograms for precursors (1)-(4), showing (\%) weight losses against temperature.

with the loss of pyridine molecules (Fig. S5a and b, ESI $\dagger$ ). The observed weight losses of 6.02 and $8.38 \%$ show some consistency with the calculated values of 5.41 and $11.31 \%$ for the loss of 0.5 and 1 molecule of pyridine from (1) and (2) respectively.

The TG profiles of non-solvated (3) and (4) did not show any weight loss in the temperature range of $70-170{ }^{\circ} \mathrm{C}$ suggesting that the initial weight losses in (1) and (2) are essentially due to the loss of the solvated pyridine molecule (Fig. S5c and d, ESI $\dagger$ ). The TG and DTG data reveal that the precursors (1), (2) and (3), (4) show major weight losses in the temperature range of 240500 and $200-500{ }^{\circ} \mathrm{C}$ with maximum heat intake steps at 380 , 385,338 and $333{ }^{\circ} \mathrm{C}$ to produce stable residue amounting to $17.70,19.20,21.78$ and $27.40 \%$ respectively. These residue masses are consistent with the theoretical values of 18.90, $19.77,22.00$ and $28.57 \%$ for the formation of PdS from (1) to (4). Continued heating of the observed final residues up to $600{ }^{\circ} \mathrm{C}$ gives no further change in weight suggesting that the complexes (1)-(4) have decomposed quantitatively to furnish PdS as a stable end product (Fig. 5).

\subsection{Material characterisation}

Three different temperatures of 400,450 and $500{ }^{\circ} \mathrm{C}$ were applied for the deposition of PdS thin films from pyridine solution of precursors (1)-(4) by AACVD. It was found that $450{ }^{\circ} \mathrm{C}$ is the most appropriate temperature for the deposition

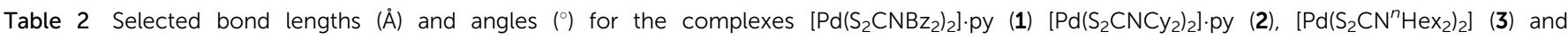
$\left[\mathrm{Pd}\left(\mathrm{S}_{2} \mathrm{CNCyMe}\right)_{2}\right](4)$

\begin{tabular}{lcclr}
\hline & $(1)$ & $(2)$ & $(3)^{a}$ & $(4)$ \\
\hline Pd1-S1 & $2.3315(5)$ & $2.3141(6)$ & $2.3272(8), 2.3241(8)$ & $2.3319(4)$ \\
Pd1-S2 & $2.3172(5)$ & $2.3237(6)$ & $2.3143(7), 2.3236(8)$ & $1.725(3), 1.720(3)$ \\
C1-S1 & $1.7220(19)$ & $1.730(2)$ & $1.724(3), 1.724(3)$ & $1.7201(5)$ \\
C1-S2 & $1.718(2)$ & $1.738(2)$ & $1.315(3), 1.317(3)$ & $1.7223(16)$ \\
N1-C1 & $1.323(2)$ & $1.326(3)$ & $75.68(3), 75.62(3)$ & $1.3273(19)$ \\
S1-Pd1-S2 & $75.329(17)$ & $75.15(2)$ & $104.51(3), 104.06(3)$ & $75.080(14)$ \\
S1-Pd1-S2' (or S4, ESI) & $104.671(17)$ & $104.85(2)$ & $111.27(16), 111.66(16)$ & $104.919(14)$ \\
S1-C1-S2 & $111.32(11)$ & $109.29(13)$ & $111.08(9)$
\end{tabular}

${ }^{a}$ (3) has no internal symmetry; second entries are bonds or angles involving S3, S4, C14 and N2 (matching S1, S2, C1 and N1, respectively). 


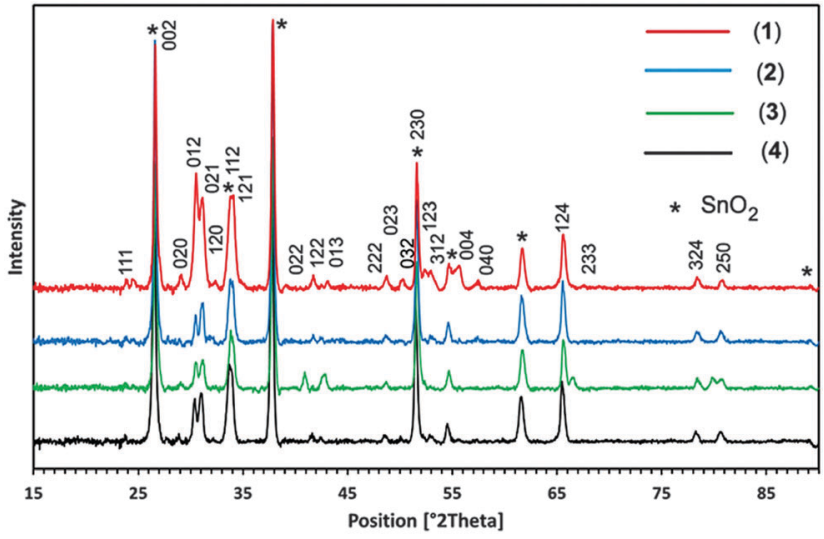

Fig. 6 XRD patterns of tetragonal-PdS films deposited from precursor $\left[\mathrm{Pd}\left(\mathrm{S}_{2} \mathrm{CNBz}_{2}\right)_{2}\right]$.py (1) (red line), $\left[\mathrm{Pd}\left(\mathrm{S}_{2} \mathrm{CNCy}_{2}\right)_{2}\right]$.py (2) (blue line), $\left[\mathrm{Pd}\left(\mathrm{S}_{2} \mathrm{CN}^{n} \mathrm{Hex}_{2}\right)_{2}\right]$ (3) (green line) and $\left[\mathrm{Pd}\left(\mathrm{S}_{2} \mathrm{CNMeCy}\right)_{2}\right]$ (4) (black line) at $450{ }^{\circ} \mathrm{C}$ on FTO glass substrate.

of PdS thin films with better adherence properties to the substrate. The films deposited at $450{ }^{\circ} \mathrm{C}$ were dark grey in colour. When the films were deposited at 400 and $500{ }^{\circ} \mathrm{C}$ from the same precursors, the films looked dark black in colour and were not adhered to the substrate wall. However, the thickness of the films deposited at 400 and $500{ }^{\circ} \mathrm{C}$ were too low to be investigated by XRD. The XRD patterns of the films deposited on FTO glass substrate at $450{ }^{\circ} \mathrm{C}$ from pyridine solution of precursors (1)-(4) are displayed in Fig. 6. A careful inspection of the recorded XRD patterns was made against PdS including $\mathrm{Pd}_{4} \mathrm{~S}, \mathrm{Pd}_{3} \mathrm{~S}, \mathrm{Pd}_{2.8} \mathrm{~S}, \mathrm{PdS}, \mathrm{PdS}_{2}$ held in the database. It was found that similar XRD patterns for the PdS thin films prepared from precursors (1)-(4) at $450{ }^{\circ} \mathrm{C}$ while diffraction peaks were indexed to standard Inorganic Crystal Structure Database ICSD = [98-064-8749] to identify the deposited product as the "Vysotskite PdS" crystallizing in the tetragonal structure $(P 42 / m)$ with crystal parameters of $a=b=6.4290$, and $c=6.6080 \AA$ А.

The diffraction peaks originating for conducting $\mathrm{SnO}_{2}$ are indexed by $\left({ }^{*}\right)$. The strong reflections produced at $2 \theta=26.60^{\circ}$, $33.84^{\circ}, 51.60^{\circ}$ are shared by both crystalline PdS and $\mathrm{SnO}_{2}$. No possible crystalline impurities such as $\mathrm{Pd}_{2.8} \mathrm{~S}, \mathrm{Pd}_{3} \mathrm{~S}, \mathrm{Pd}_{4} \mathrm{~S}, \mathrm{Pd}_{2.2} \mathrm{~S}$ and $\mathrm{Pd}_{2.5} \mathrm{~S}$ were detected from these XRD patterns. This clearly indicates that all the precursors (1)-(4) decompose cleanly at $450{ }^{\circ} \mathrm{C}$ to yield the pure crystalline tetragonal phase of PdS.

Recently, PdS thin films deposited from $\left[\mathrm{Pd}\left(\mathrm{S}_{2} \mathrm{CNRR}^{\prime}\right)_{2}\right]$ $\left(\mathrm{RR}^{\prime}=\mathrm{Et}_{2}, \mathrm{MeEt}, \mathrm{Me}{ }^{n} \mathrm{Bu}\right)$ complexes showed widely differing results depending on the type of precursor and growth temperature. ${ }^{19}$ Poorly crystalline films of tetrahedral $\mathrm{Pd}_{4} \mathrm{~S}$ were deposited from $\operatorname{Pd}\left(\mathrm{S}_{2} \mathrm{CNEt}_{2}\right)_{2}$ and mixtures of tetragonal PdS and cubic $\operatorname{Pd}_{16} \mathrm{~S}_{7}$ were deposited from $\operatorname{Pd}\left(\mathrm{S}_{2} \mathrm{CNMeEt}\right)_{2}$ at $450{ }^{\circ} \mathrm{C}$. The deposition from $\mathrm{Pd}\left(\mathrm{S}_{2} \mathrm{CNMe}^{n} \mathrm{Bu}\right)_{2}$ at temperatures of 475,500 and $525{ }^{\circ} \mathrm{C}$ resulted in $\mathrm{Pd}_{16} \mathrm{~S}_{7}$, mixtures of $\mathrm{Pd}_{16} \mathrm{~S}_{7}$ and tetrahedral $\mathrm{Pd}_{4} \mathrm{~S}$ and cubic Pd respectively. ${ }^{19}$

The formation of stoichiometric tetragonal PdS thin films in our AACVD experiments coincides with previous investigations ${ }^{17,18}$ for low pressure and photochemical CVD experiments using dithiocarbamate $\left[\mathrm{Pd}\left(\mathrm{S}_{2} \mathrm{CNMeHex}\right)_{2}\right]$ and xanthate $\left[\mathrm{Pd}\left(\mathrm{S}_{2} \mathrm{COCHMe}_{2}\right)_{2}\right]$ precursors respectively. These observations suggest that the molecular design of precursors, deposition technique and temperature play a vital role in determining the nature of PdS deposition.

Furthermore, thermal decomposition of allyl palladium dithiocarbamate/xanthate SSPs for the generation of palladium sulphide $\left(\mathrm{PdS}, \mathrm{Pd}_{4} \mathrm{~S}, \mathrm{Pd}_{x} \mathrm{~S}\right.$ ) powders have been widely studied and explored in the past. For example, the thermal decomposition of allyl palladium dithiocarbamates $\left[\left(\eta^{3}-\mathrm{C}_{3} \mathrm{H}_{5}\right) \mathrm{Pd}\left(\mathrm{S}_{2} \mathrm{CNC}_{5} \mathrm{H}_{10}\right)\right]$ and $\left[\left(\eta^{3}-\mathrm{C}_{4} \mathrm{H}_{7}\right) \operatorname{Pd}\left(\mathrm{S}_{2} \mathrm{CNPr}_{2}\right)\right]$ having a similar $\mathrm{Pd}: \mathrm{S}(2: 1)$ ratio decomposed to PdS and PdS-Pd composite respectively. ${ }^{20}$ The thermal decomposition of allyl palladium xanthate $\left[\left(\eta^{3}-\mathrm{CH}_{2} \mathrm{C}\left(\mathrm{CH}_{3}\right) \mathrm{CH}_{2}\right) \mathrm{Pd}\left(\mathrm{S}_{2} \mathrm{X}\right)\right] \quad\left(\mathrm{X}=\mathrm{COMe} ; \mathrm{COEt} ; \mathrm{CO}^{\mathrm{i}} \mathrm{Pr}\right)$, $\left[\left(\eta^{3}-\mathrm{CH}_{2} \mathrm{C}\left(\mathrm{CH}_{3}\right) \mathrm{CH}_{2}\right) \mathrm{Pd}\left(\mathrm{S}_{2} \mathrm{COMe}\right)\right]$ and palladium xanthate $\left[\mathrm{Pd}\left(\mathrm{S}_{2} \mathrm{COMe}\right)_{2}\right]$ having different alkyl groups and same $\mathrm{Pd}: \mathrm{S}$ $(2: 1)$ ratio result in the formation of a single phase PdS as the end product. ${ }^{14}$ Furthermore, the thermal decomposition of an allyl palladium dithiophosphinate complex, $\left[\left(\eta^{3}-\mathrm{C}_{4} \mathrm{H}_{7}\right) \mathrm{Pd}\left(\mathrm{S}_{2} \mathrm{PPh}_{2}\right)\right]$ and an organosulphur-bridged dimeric 2-methylallylpalladium complex $\left[\mathrm{Pd}_{2}\left(\mu-\mathrm{SBu}^{t}\right)_{2}\left(\eta^{3}-\mathrm{C}_{4} \mathrm{H}_{7}\right)_{2}\right]$ having different Pd:S ratios yielded the same metal-rich palladium sulphide $\left(\mathrm{Pd}_{4} \mathrm{~S}\right)$ material. ${ }^{14}$ The forgoing discussion summarizes that during thermal treatments at certain higher temperatures the precursor molecules absorb specific thermal energies that allow simultaneous and multiple bond breaking of the precursor molecules sometimes causing non-selective bond dissociation of the precursor molecule to yield variable products. Moreover the ratio of $\mathrm{Pd}: \mathrm{S}$ in the precursor may play an important role in deciding the nature of the end product.

\subsection{Structural characterisation}

The influence of solvents on the morphologies of films deposited by AACVD can be significant and is dependent upon the materials being deposited and the precursors used. Although the complexes (1)-(4) are highly soluble in common organic solvents chloroform, methanol and pyridine, the selection of deposition solvent (pyridine) is made on the basis of its physical properties i.e. boiling point, heat of combustion and coordinating ability. Based on our recent investigations, ${ }^{22,23}$ pyridine having coordinating ability with a high boiling point $\left(115^{\circ} \mathrm{C}\right)$ and heat of combustion $\left(2782 \mathrm{~kJ} \mathrm{~mol}^{-1}\right)$ facilitates both the homogeneous and heterogeneous nucleation and helps in building novel design and morphologies. In contrast, methanol and chloroform have low boiling points of 64.7 and $61.2{ }^{\circ} \mathrm{C}$ and have much lower heats of combustion of 725 and $473 \mathrm{~kJ} \mathrm{~mol}^{-1}$ respectively, and which evaporate faster compared to pyridine, causing unwanted homogenous nucleation to generate ultrafine particles that are embedded into the thin film and cause deterioration to the film properties such as crystallinity, microstructure and uniformity. ${ }^{34,35}$

SEM images of the thin films prepared using pyridine solutions of the precursors (1)-(4) on FTO glass substrates at temperatures 400,450 and $500{ }^{\circ} \mathrm{C}$ are presented in Fig. 7 that indicates that the shape, texture and morphology of PdS films developed from precursors (1) to (3) vary with the increase in deposition temperature while precursor (4) builds similar PdS architectures at all temperatures from 400 to $500{ }^{\circ} \mathrm{C}$. SEM images of all the films grown from (1) to (4) at 400, 450 and 


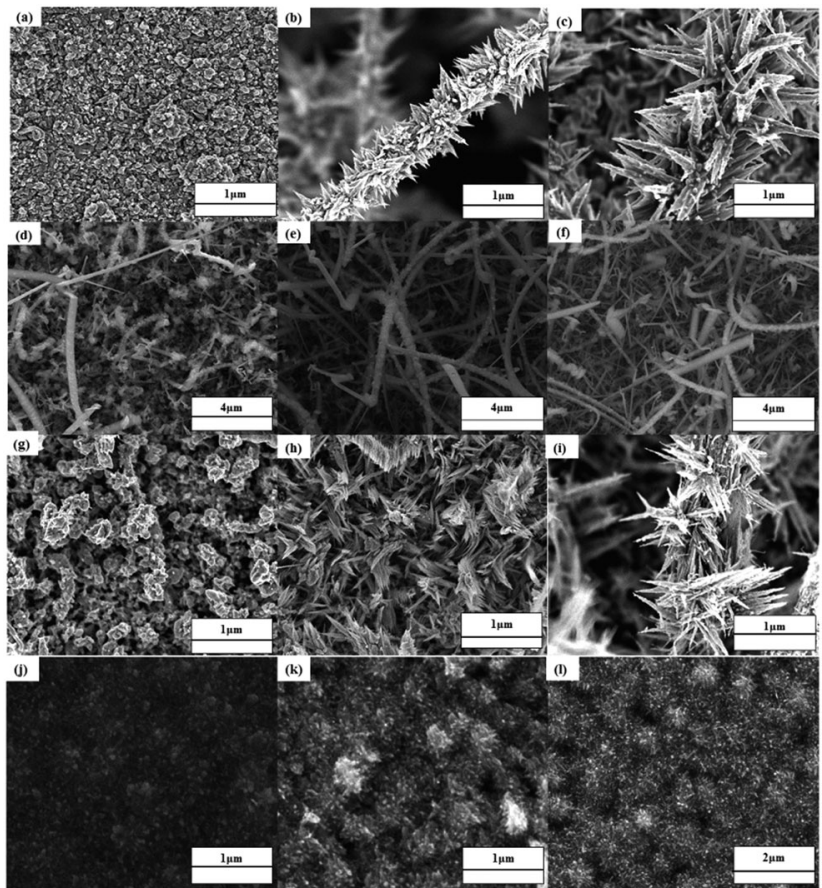

Fig. 7 SEM images of PdS thin films deposited using precursors $\left[\mathrm{Pd}\left(\mathrm{S}_{2} \mathrm{CNBz}_{2}\right)_{2}\right] \cdot$ py (1), $\quad\left[\mathrm{Pd}\left(\mathrm{S}_{2} \mathrm{CNCy}_{2}\right)_{2}\right] \cdot$ py $\quad$ (2), $\quad\left[\mathrm{Pd}\left(\mathrm{S}_{2} \mathrm{CN}^{n} \mathrm{Hex}_{2}\right)_{2}\right] \quad$ (3), $\left[\mathrm{Pd}\left(\mathrm{S}_{2} \mathrm{CNCyMe}\right)_{2}\right](\mathbf{4})$ at $400{ }^{\circ} \mathrm{C}$, (a), (d), (g), (j); $450{ }^{\circ} \mathrm{C}$, (b), (e), (h), (k), and $500{ }^{\circ} \mathrm{C},(\mathrm{c}),(\mathrm{f}),(\mathrm{i}),(\mathrm{l})$, respectively.

$500{ }^{\circ} \mathrm{C}$ are shown in Fig. 7(a)-(l) and a description of their morphologies and $\mathrm{Pd}: \mathrm{S}$ ratio in the thin films is given in Table 3. It can be seen that with the increase in the deposition temperature from 400 to $450{ }^{\circ} \mathrm{C}$, thin film growth rates from all precursors (1)-(4) become better and the substrate surface is covered with different directional morphologies of PdS (Table 3). Upon further increase in the deposition temperature to $500{ }^{\circ} \mathrm{C},(\mathbf{1})$ developed acacia thorn tree design, (2) produced uneven shaped nanowires, (3) produced thorn design and (4) remained almost unchanged. The elemental composition as determined by EDX analysis (Fig. S7a-d, ESI $\dagger$ ) shows stoichiometric $\mathrm{Pd}: \mathrm{S}$ at $1: 1$ indicating formation of vysotskite-structured PdS that is further verified by the XRD results.

\subsection{Optical characterization}

The optical band gap energy $\left(E_{\mathrm{g}}\right)$ of PdS thin films deposited from precursor (2) at $450{ }^{\circ} \mathrm{C}$ was determined using spectrophotometry and is shown in Fig. 8. The UV-Vis spectra of the film recorded in the wavelength range between 400 and $900 \mathrm{~nm}$ shows that the PdS films are capable of absorbing sunlight over the entire visible part of solar spectrum, as indicated by the Fig. 8(a).

The optical band gap $\left(E_{\mathrm{g}}\right)$ value was derived from the eqn (2) below:

$$
(\alpha h \nu)^{1 / n}=A\left(h \nu-E_{\mathrm{g}}\right) \ldots
$$

where $\alpha$ is the absorption coefficient, $A$ is a constant, $h \nu$ the photon energy and $n$ is an exponent, which differentiate between direct allowed $(n=1 / 2)$, direct forbidden $(n=3 / 2)$, allowed indirect $(n=2)$, and forbidden indirect $(n=3)$ transitions. The direct allowed optical band gap $(n=1 / 2)$ was estimated from the Tauc plot by plotting $(\alpha h \nu)^{2}$ versus photonic energy $(h \nu)$ and extending the linear part of the curve on the energy axis and were measured to be $1.56 \mathrm{eV}$ (Fig. 8(b)). The other types of optical bandgaps such as allowed indirect $(n=2)$, forbidden direct $(n=3 / 2)$ and forbidden indirect $(n=3)$ measured from their Tauc plots and found to be $0.75,0.95$ and $0.87 \mathrm{eV}$ respectively and data are provided in Fig. S8(c)-(e) (ESI $\dagger)$. The thickness of the PdS films used for the optical experiments was measured by the profilometer, which was $180 \mathrm{~nm}$. Our band gap value shows a good match with that of PdS thin films prepared by other methods. ${ }^{11}$

\subsection{Photoelectrochemical characterisation}

The chopped current-voltage measurements, in the dark and under illumination, were measured in a conventional threeelectrode electrochemical set-up with $\mathrm{Ag} / \mathrm{AgCl}$ as the reference electrode and a platinum mesh as the counter electrode. An aqueous electrolyte of $1 \mathrm{M} \mathrm{Na}_{2} \mathrm{SO}_{3}$ was used for the measurements. Fig. 9 shows the photocurrent response in the PEC measurements of PdS electrodes fabricated using precursor (2) at $450{ }^{\circ} \mathrm{C}$ with a photocurrent onset of $-0.3 \mathrm{~V}(v s . \mathrm{Ag} / \mathrm{AgCl} / 3 \mathrm{M} \mathrm{KCl})$. The plot indicates that the PdS electrode exhibited an anodic photocurrent which increases with increasing applied bias. The film deposited from precursor (2) showed a reasonable photocurrent response compared to the film obtained from the other precursor solutions at $450{ }^{\circ} \mathrm{C}$. This could be due to the higher internal surface acquired from the randomly oriented nanowire structure of the film (Fig. 7e). The film showed a maximum net photocurrent density of $4 \mu \mathrm{A} \mathrm{cm} \mathrm{cm}^{-2}$ at $0 \mathrm{~V} v s$. $(\mathrm{Ag} / \mathrm{AgCl} / 3 \mathrm{M} \mathrm{KCl})$. However, the dark current of the films is pronounced with the applied bias which is probably an indication of the oxidation of sulphide electrode surface upon illumination, which is well known phenomenon. ${ }^{36,37}$ To the best of our knowledge this is the first demonstration of the PEC properties of a PdS thin film. The photoactivity of the PdS films indicates their potential

Table 3 Description of morphologies [Fig. 7(a)-(l)] and Pd:S elemental ratio as determined by EDX in thin films fabricated from precursors (1) -(4) at 400,450 and $500{ }^{\circ} \mathrm{C}$

\begin{tabular}{|c|c|c|c|}
\hline \multirow{2}{*}{$\begin{array}{l}\text { Type of } \\
\text { Precursor }\end{array}$} & \multicolumn{3}{|c|}{ Deposition temperatures $\left({ }^{\circ} \mathrm{C}\right)$, morphology, $\mathrm{Pd} / \mathrm{S}$ ratio } \\
\hline & 400 & 450 & 500 \\
\hline (1) & (a) Densely packed grains (37.14): (34.23) & (b) Cactus branch (31.41): (29.98) & (c) Acacia thorn (21.34):(20.13) \\
\hline (3) & (g) Irregular shape crystallites (39.19): (35.71) & (h) Featureless pattern $(20.33):(20.29)$ & (i) Thorn design $(25.36):(23.89)$ \\
\hline (4) & (j) Heap of crystallites $(12.23):(11.69)$ & (k) Heap of crystallites (28.25):(31.19) & (1) Heap of crystallites $(20.53):(23.40)$ \\
\hline
\end{tabular}



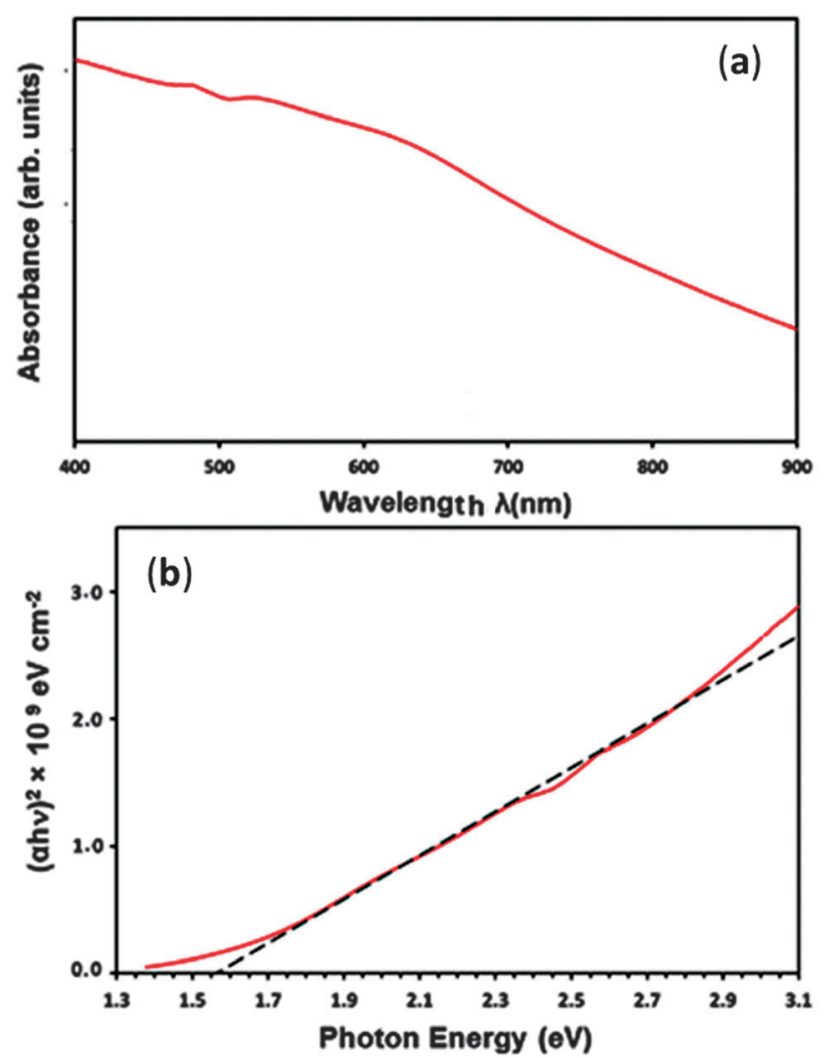

Fig. 8 (a) UV-Vis spectra of PdS thin films deposited using precursor (2) at $450{ }^{\circ} \mathrm{C}$ (b) shows the direct band gap of $1.56 \mathrm{eV}$ for PdS films.

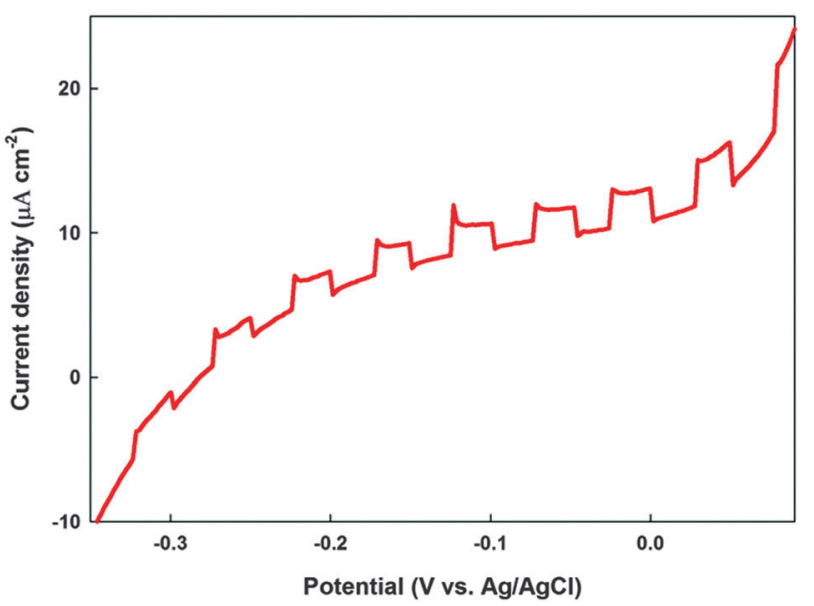

Fig. 9 Chopped current-voltage curve for PdS thin film deposited using precursor (2) at $450{ }^{\circ} \mathrm{C}$ on the FTO substrate.

to be further developed for being used in light harvesting applications (i.e. PV cells, PEC water splitting devices, PEC $\mathrm{CO}_{2}$ conversion devices).

\section{Conclusions}

The present work describes the synthesis, characterization and application of a series of palladium dithiocarbamate complexes as single source precursors for the growth of palladium sulphide thin films on fluorine doped tin oxide coated conducting glass substrate at temperatures of 400,450 and $500{ }^{\circ} \mathrm{C}$ using the aerosol-assisted chemical vapour deposition technique. Powder $\mathrm{X}$-ray diffraction data indicate the deposited product as single phase vysotskite PdS from all complexes (1)-(4) and energy dispersive X-ray spectroscopy verifies the 1:1 stoichiometry of the thin films deposited under similar conditions indicate that the texture, shape and size of the PdS strongly depend on the nature of the precursor used. The ultraviolet visible spectroscopy measurements of the palladium sulphide films showed that band gap energies $\left(E_{\mathrm{g}}\right)$ of $1.56 \mathrm{eV}$, suggesting the applicability of films in photoelectrochemical and photocatalytic devices/systems. The palladium sulphide film deposited from precursor (2) at $450{ }^{\circ} \mathrm{C}$ exhibited a net photocurrent density of $4 \mu \mathrm{A} \mathrm{cm}{ }^{-2}$ at $0 \mathrm{~V}$ applied bias (vs. $\mathrm{Ag} / \mathrm{AgCl} / 3 \mathrm{M} \mathrm{KCl})$. The photoelectrochemical data confirm that these single source precursors are suitable for obtaining photoactive palladium sulphide thin films using the aerosolassisted chemical vapour deposition method for a range of light harvesting applications.

\section{Acknowledgements}

The authors acknowledge the High-Impact Research scheme (Grant numbers UM.S/P/628/3(HIR-MOHE-SC21), UM.C/625/1/ HIR/131) and the UMRG scheme (Grant number RP007A13AET) for funding this research. UW and TANP would like to acknowledge the support from EPSRC and Johnson Matthey Plc.

\section{Notes and references}

1 C. I. Pearce, R. A. Pattrick and D. J. Vaughan, Rev. Mineral. Geochem., 2006, 61, 127-180.

2 X. Li, H. Shen, S. Li, J. Z. Niu, H. Wang and L. S. Li, J. Mater. Chem., 2010, 20, 923-928.

3 C. M. Grgicak and J. B. Giorgi, J. Phys. Chem. C, 2007, 111, 15446-15455.

4 H. Karami and S. Babaei, Int. J. Electrochem. Sci., 2013, 8.

5 C.-H. Lai, K.-W. Huang, J.-H. Cheng, C.-Y. Lee, B.-J. Hwang and L.-J. Chen, J. Mater. Chem., 2010, 20, 6638-6645.

6 C.-H. Lai, M.-Y. Lu and L.-J. Chen, J. Mater. Chem., 2012, 22, 19-30.

7 Y. Chen, G.-F. Huang, W.-Q. Huang, B. Zou and A. Pan, Appl. Phys. A: Mater. Sci. Process., 2012, 108, 895-900.

8 J. Folmer, J. Turner and B. Parkinson, J. Solid State Chem., 1987, 68, 28.

9 A. Mashkina and L. Sakhaltueva, Kinet. Catal., 2002, 43, 107-114.

10 P. Raybaud, J. Hafner, G. Kresse and H. Toulhoat, J. Phys.: Condens. Matter, 1997, 9, 11107.

11 I. Ferrer, P. Díaz-Chao, A. Pascual and C. Sánchez, Thin Solid Films, 2007, 515, 5783-5786.

12 K. E. K. Yamamoto, K. Endo, Y. Takaya and E. Kaneda, Japanese Patent, 62/226,155, Mitsubishi Paper Mills Ltd., 1987. 
13 H. Kyama and T. Iwata, Japanese Patent, 08/095,209, Mitsubishi Paper Mills Ltd., 1996.

14 A. Singhal, D. P. Dutta, A. K. Tyagi, S. M. Mobin, P. Mathur and I. Lieberwirth, J. Organomet. Chem., 2007, 692, 5285-5294.

15 E. Matijević, J. Eur. Ceram. Soc., 1998, 18, 1357-1364.

16 T. Yamamoto, K. Tanaka, E. Kubota and K. Osakada, Chem. Mater., 1993, 5, 1352-1357.

17 J. Cheon, D. S. Talaga and J. I. Zink, Chem. Mater., 1997, 9, 1208-1212.

18 M. A. Malik, P. O'Brien and N. Revaprasadu, J. Mater. Chem., 2002, 12, 92-97.

19 P. O'Brien and J. Waters, Chem. Vap. Deposition, 2006, 12, 620-626.

20 A. Birri, B. Harvey, G. Hogarth, E. Subasi and F. Uğur, J. Organomet. Chem., 2007, 692, 2448-2455.

21 M. A. Ehsan, H. Khaledi, A. A. Tahir, H. N. Ming, K. Wijayantha and M. Mazhar, Thin Solid Films, 2013, 536, 124-129.

22 M. A. Ehsan, H. N. Ming, M. Misran, Z. Arifin, E. R. Tiekink, A. P. Safwan, M. Ebadi, W. J. Basirun and M. Mazhar, Chem. Vap. Deposition, 2012, 18, 191-200.

23 M. A. Ehsan, T. N. Peiris, K. Wijayantha, H. Khaledi, H. N. Ming, M. Misran, Z. Arifin and M. Mazhar, Thin Solid Films, 2013, 540, 1-9.

24 M. A. Ehsan, T. N. Peiris, K. U. Wijayantha, M. M. Olmstead, Z. Arifin, M. Mazhar, K. Lo and V. McKee, Dalton Trans., 2013, 42, 10919-10928.

25 A. A. Tahir, M. A. Ehsan, M. Mazhar, K. U. Wijayantha, M. Zeller and A. Hunter, Chem. Mater., 2010, 22, 5084-5092.
26 M. A. Mansoor, M. A. Ehsan, V. McKee, N.-M. Huang, M. Ebadi, Z. Arifin, W. J. Basirun and M. Mazhar, J. Mater. Chem. A, 2013, 1, 5284-5292.

27 M. A. Mansoor, A. Ismail, R. Yahya, Z. Arifin, E. R. Tiekink, N. S. Weng, M. Mazhar and A. R. Esmaeili, Inorg. Chem., 2013, 52, 5624-5626.

28 M. Brewer, D. Khasnis, M. Buretea, M. Berardini, T. Emge and J. Brennan, Inorg. Chem., 1994, 33, 2743-2747.

29 A. A. Tahir, K. U. Wijayantha, S. Saremi-Yarahmadi, M. Mazhar and V. McKee, Chem. Mater., 2009, 21, 3763-3772.

30 G. M. Sheldrick, Acta Crystallogr., Sect. A: Found. Crystallogr., 2008, 64, 112-122.

31 J. Akhtar, M. A. Malik, P. O’Brien, K. Wijayantha, R. Dharmadasa, S. J. Hardman, D. M. Graham, B. F. Spencer, S. K. Stubbs, W. R. Flavell, D. J. Binks, F. Sirotti, M. ElKazzi and M. Silly, J. Mater. Chem., 2010, 20, 2336-2344.

32 A. Torres-Huerta, H. Höpfl, H. Tlahuext, I. F. HernándezAhuactzi, M. Sánchez, R. Reyes-Martínez and D. MoralesMorales, Eur. J. Inorg. Chem., 2013, 61-69.

33 V. Alverdi, L. Giovagnini, C. Marzano, R. Seraglia, F. Bettio, S. Sitran, R. Graziani and D. Fregona, J. Inorg. Biochem., 2004, 98, 1117-1128.

34 X. Hou and K. L. Choy, Chem. Vap. Deposition, 2006, 12, 583-596.

35 P. Marchand, I. A. Hassan, I. P. Parkin and C. J. Carmalt, Dalton Trans., 2013, 42, 9406-9422.

36 M. T. S. Nair and P. K. Nair, Semicond. Sci. Technol., 1900, 5, 1225-1230.

37 F. B. Michelett and P. Mark, Appl. Phys. Lett., 1967, 10, 136-138. 